\title{
Uji Klirens dan Uji Pirogenitas sebagai Bagian dari Penentuan Mutu Biologi Sediaan ${ }^{90}$ Y-EDTMP
}

\author{
Clearance and Pyrogen Test as A Part of Determining \\ The ${ }^{90}$ Y-EDTMP Biological Quality
}

\author{
Sulaiman*, Sri Aguswarini, Karyadi, Chairuman, Gatot Setiawan, Adang HG, M Subur \\ Pusat Teknologi Radioisotop dan Radiofarmaka-BATAN, Serpong, Indonesia \\ *E-mail: sulaiman@batan.go.id
}

Diterima: 12 Januari 2018

Direvisi: 23 April 2018

Disetujui: 26 Juli 2018

\begin{abstract}
Abstrak
Kanker merupakan salah satu penyebab kematian di Indonesia bahkan dunia. Teknik kedokteran nuklir dengan radiofarmaka dan SPECT merupakan salah satu cara pengobatan kanker, namun penggunaannya di Indonesia belum populer. Radiofarmaka bertanda radionuklida pemancar radiasi beta $(\beta)$ terbukti dapat digunakan untuk terapi kanker, salah satu yang telah dikembangkan di PTRR-BATAN yaitu ${ }^{90}$ Y-EDTMP. Itrium-90 digunakan di kedokteran nuklir dengan memanfaatkan radiasi $\beta$ (E max $2.28 \mathrm{MeV}$ ). Energi $\beta$ yang dihasilkan dari proses peluruhan radionuklida ${ }^{90} \mathrm{Y}$ menjadi ${ }^{90} \mathrm{Zr}$ dapat mematikan sel-sel kanker. Tujuan dari penelitian ini adalah untuk memberikan informasi tentang efek biologis zat sehingga bisa diambil tindakan pencegahan untuk melindungi manusia. Pada penelitian ini dilakukan pengujian terhadap radiofarmaka bertanda ${ }^{90} \mathrm{Y}\left({ }^{90} \mathrm{Y}\right.$ dihasilkan dari generator ${ }^{90} \mathrm{Sr} /{ }^{90} \mathrm{Y}$ yaitu ${ }^{90} \mathrm{Y}$-EDTMP) meliputi uji clearance, uji pirogenitas, dan uji keamanan dosis pada hewan coba. Uji clearance menggunakan tikus, uji pirogenitas menggunakan kelinci, dan uji keamanan menggunakan mencit. Hasil uji clearance menunjukkan senyawa ${ }^{90}$ Y-EDTMP yang diekskresikan dalam rentang waktu 192 jam adalah 49,70\% melalui urine dan 14,59\% melalui feses. Total ekskresi ${ }^{90} \mathrm{Y}$-EDTMP selama selang waktu 192 jam adalah sebesar 64,57\%. Berdasarkan hasil uji clearance dengan perhitungan maka ${ }^{90} \mathrm{Y}$ dari generator ${ }^{90} \mathrm{Sr} /{ }^{90} \mathrm{Y}$ dalam bentuk sediaan ${ }^{90} \mathrm{Y}$-EDTMP memiliki waktu paruh 84,2 jam, waktu paruh efektif 36,5 jam dan waktu tinggal (residence time) 52,7 jam. Hasil uji pirogen menunjukkan sediaan bebas pirogen. Kajian keamanan ${ }^{90}$ Y-EDTMP menunjukkan dosis yang digunakan masih dalam batasan aman dan tidak mematikan. Pengembangan sediaan ini diharapkan dapat disempurnakan untuk menghasilkan radiofarmaka terapi kanker untuk memberikan kontribusi yang nyata pada pelayanan kesehatan masyarakat.
\end{abstract}

Kata kunci: Generator ${ }^{90} \mathrm{Sr} /{ }^{90} \mathrm{Y}$; Uji clearance; Uji pirogenitas; ${ }^{90} \mathrm{Y}$-EDTMP; ${ }^{90} \mathrm{YCl}_{3}$.

\begin{abstract}
Cancer is one of the causes of death in Indonesia and even the world. Nuclear medicine techniques with radiopharmaceuticals and SPECT are one of the ways to treat cancer, but their use in Indonesia is not yet popular. Radiopharmaceuticals marked with radionuclide emitting beta $(\beta)$ radiation are proven to be used for cancer therapy, one that has been developed in PTRR-BATAN is 90Y-EDTMP. Yttrium-90 is used in nuclear medicine by utilizing $\beta$ radiation ( $E \max 2.28 \mathrm{MeV}$ ). The $\beta$ energy which is produced from the decay process of $90 Y$ radionuclides to $90 \mathrm{Zr}$ can kill cancer cells. This study aimed to provide information about the substances biological effects so that preventive measures can be taken to protect humans. This study conducted evaluation of the 90Y-marked radiopharmaceutical (90Y produced from a 90Sr / 90Y generator which is 90Y-EDTMP) encompasses clearance test, pyrogen test, and dose safety test in experimental animals. The clearance test utilized mice, the pyrogen test utilized rabbits, and the dose safety test utilized mice. The results of the clearance test showed that 90Y-EDTMP compound which was excreted in 192 hour was $49.70 \%$ through urine and $14.59 \%$ through feces. The total excretion of 90Y-EDTMP within 192 hours was $64.57 \%$. Based on the results of clearance tests with calculations, $90 \mathrm{Y}$ of $90 \mathrm{Sr} / 90 \mathrm{Y}$ generators in 90Y-EDTMP dosage form had 84.2 hours of half-life, 36.5 hours of an effective half-life and 52.7 hours of a residence time. Pyrogen test results showed pyrogen-free. The 90Y-EDTMP dose safety test showed that the dose is safe and not deadly. The development of 90Y-EDTMP is expected to be improved to produce radiopharmaceuticals for cancer therapy in order to make a real contribution in public health services.
\end{abstract}

Keywords: Clearance test; Pyrogen test; ${ }^{90} \mathrm{Sr} /{ }^{90} \mathrm{Y}$ generator; ${ }^{90} \mathrm{Y}-\mathrm{EDTMP} ;{ }^{90} \mathrm{YCl}_{3}$. 


\section{PENDAHULUAN}

Itrium-90 yang memiliki sifat kimia mirip dengan lantanoid ${ }^{1}$ seperti ${ }^{166} \mathrm{Ho},{ }^{177} \mathrm{Lu}$, dan ${ }^{153} \mathrm{Sm}$ banyak digunakan untuk terapi penyakit kanker di kedokteran nuklir. Terapi tersebut dilakukan dengan memanfaatkan energi $\beta$ - yang dihasilkan dari proses peluruhan ${ }^{90} \mathrm{Y}$ menjadi ${ }^{90} \mathrm{Zr}$. Itrium-90 memiliki energi $\beta$ - $\max$ sebesar $2,28 \mathrm{MeV}$, tidak memiliki radiasi gamma, dan waktu paruh (T1/2) 64,4 jam. ${ }^{2,3}$ Untuk memperoleh ${ }^{90} \mathrm{Y}$ yang bebas pengemban dilakukan pemisahan dari ${ }^{90} \mathrm{Sr}$ yang diperoleh dari hasil fisi. Stronsium-90 memiliki waktu paruh (T1/2) selama 28,74 tahun dengan memancarkan energi $\beta$ - $0,54 \mathrm{MeV}$. Peluruhannya mengikuti rumus sebgai berikut: ${ }^{4}$

$$
A_{2}=\frac{\lambda_{2}}{\lambda_{2}-\lambda_{1}} A_{10}\left(e^{-\lambda_{2} t}-e^{-\lambda_{1} t}\right)
$$

$\mathrm{A}_{10}$ : Aktivitas ${ }^{90} \mathrm{Sr}$ awal

$\mathrm{A}_{2}$ : Aktivitas ${ }^{90} \mathrm{Y}$ yang terbentuk

$\lambda_{1}$ : Konstanta peluruhan ${ }^{90} \mathrm{Sr}$

$\lambda_{2}$ : Konstanta peluruhan ${ }^{90} \mathrm{Y}$

$\mathrm{t}:$ Waktu

${ }^{90} \mathrm{Sr}$ mempunyai waktu paruh yang sangat panjang dan beracun $^{3}$ sehingga perlu penanganan yang teliti agar radionuklida ${ }^{90} \mathrm{Y}$ hasil pemisahan mengandung ${ }^{90} \mathrm{Sr}$ sekecil mungkin. Beberapa metode pemisahan untuk mendapatkan ${ }^{90} \mathrm{Y}$ dari ${ }^{90} \mathrm{Sr}$ adalah: adsorpsi, ekstraksi pelarut, pengendapan, pertukaran ion, kromatografi kolom, pertukaran kation, kromatografi kertas, sistem membran, dan pemisahan elektrokimia. ${ }^{5}$

Metode yang dikembangkan saat ini oleh PTRR-BATAN untuk mendapatkan ${ }^{90} \mathrm{Y}$ adalah dengan sistem generator (generator $\left.{ }^{90} \mathrm{Sr} /{ }^{90} \mathrm{Y}\right)$ berbasis elektrokromatografi. ${ }^{6}$ Itrium-90 dalam penggunaannya dapat direaksikan dengan bermacam ligan antara lain etilen diamin tetra metilen phosphonate (EDTMP) menghasilkan senyawa radiofarmaka ${ }^{90}$ Y-EDTMP. ${ }^{4}$ Radiofarmaka ${ }^{90}$ Y-EDTMP selama ini digunakan untuk terapi kanker tulang dan leukemia. ${ }^{1}$

Dalam penelitian sebelumnya hasil uji kualitas radionuklida ${ }^{90} \mathrm{Y}$ meliputi uji kemurnian radionuklida ${ }^{90} \mathrm{Y}$, kandungan pengotor radionuklida ${ }^{90} \mathrm{Sr}$, uji kemurnian radiokimia hasil penandaan EDTMP dengan ${ }^{90} \mathrm{Y}$ dan uji biodistribusi ${ }^{90} \mathrm{Y}$-EDTMP. Hasil uji biodistribusi ${ }^{90}$ Y-EDTMP menunjukkan bahwa sediaan tersebut terakumulasi di tulang. 4

Pengujian biologis terhadap suatu sediaan radiofarmaka dilakukan sesuai dengan peruntukan pemakaiannya pada manusia meliputi uji clearance, uji keamanan dan uji pirogenitas.

Uji clearance dimaksudkan untuk melihat kecenderungan ekskresi melalui urine atau feses suatu radiofarmaka dan seberapa lama atau seberapa cepat radiofarmaka dapat diekskresikan keluar tubuh. ${ }^{7}$ Hasil uji clearence dapat menunjukkan waktu paruh biologis, waktu paruh efektif, dan waktu tinggal (residence time) dengan perhitungan sebagai berikut. ${ }^{8}$

$$
\begin{gathered}
\frac{1}{T_{\text {efektif }}}=\frac{1}{T_{\text {bio }}}+\frac{1}{T_{\text {fis }}} \\
\left(\text { Residence time) } \mathrm{T}=\frac{\mathrm{T} 1 / 2_{\text {efektif }}}{\ln (2)}\right.
\end{gathered}
$$

Tujuan dari pengujian keamanan adalah untuk memberikan informasi tentang efek biologis zat sehingga bisa diambil tindakan pencegahan untuk melindungi manusia. Beberapa tes yang melibatkan penggunaan hewan secara langsung dimaksudkan untuk memprediksi kemungkinan dampak bahan kimia terhadap spesies selain manusia (lingkungan toksikologi) tetapi sebagian besar dimaksudkan untuk memberikan informasi yang dianggap perlu untuk melindungi kesehatan manusia. Penggunaan hewan dalam uji keamanan dosis adalah untuk memperoleh gambaran data keamanan dosis pada manusia. ${ }^{9}$

Uji pirogen dimaksudkan untuk membatasi resiko reaksi demam pada tingkat yang dapat diterima oleh pasien pada pemberian sediaan injeksi. Pirogen merupakan hasil pertumbuhan dan metabolisme dari mikroba patogen berupa 
polipeptida, polisakarida, dan nukleotida yang dalam jumlah sangat kecil (kurang dari $10 \mathrm{mg} / \mathrm{kg}$ berat badan) dapat menyebabkan demam, muntah, dan menggigil. ${ }^{10,11}$ Pengujian meliputi pengukuran kenaikan suhu kelinci setelah penyuntikan larutan uji secara intravena dan ditujukan untuk sediaan yang dapat ditoleransi kelinci dengan dosis penyuntikan tidak lebih dari $10 \mathrm{~mL}$ per $\mathrm{kg}$ bobot badan. ${ }^{10,12}$

Penelitian ini bertujuan untuk melengkapi data uji biologis pada sediaan ${ }^{90}$ Y-EDTMP dengan melakukan uji clearance, pirogenitas, dan keamanan menggunakan hewan coba. Itrium-90 yang diperoleh dari generator ${ }^{90} \mathrm{Sr} /{ }^{90} \mathrm{Y}$ diproses menjadi ${ }^{90} \mathrm{YCl}_{3}$ digunakan untuk penandaan EDTMP dengan hasil akhir dalam bentuk sediaan ${ }^{90}$ Y-EDTMP.

Penelitian yang dilakukan akan memperoleh hasil uji clearance, uji pirogenitas, dan uji keamanan menggunakan hewan coba tikus, kelinci, dan mencit terhadap sediaan ${ }^{90}$ Y-EDTMP. Penelitian ini sudah mendapat persetujuan etik dari Komisi Etik Penggunaan dan Pemeliharaan Hewan Percobaan BATAN nomor 002/KEPPHPBATAN/III/2013.

\section{METODE}

Penelitian ini merupakan penelitian eksperimental laboratorium. Dilakukan di Pusat Teknologi Radioisotop dan Radiofarmaka BATAN.

\section{Alat dan bahan}

Bahan-bahan yang digunakan adalah ${ }^{90} \mathrm{Y}$ hasil elusi dari generator ${ }^{90} \mathrm{Sr} /{ }^{90} \mathrm{Y}$ (lokal, PTRR-BATAN), asam klorida $37 \%$ pa (MERCK), dapar sitrat 0,025 M pH 5, dapar sitrat $0,1 \mathrm{M} \mathrm{pH} 5$, diamonium sitrat (Merck), alumunium oksida 90 aktif $\mathrm{N}$ (Merck), Dowex AG50Wx8 hydrogen form 100-200 mesh (sigma 217506), $\mathrm{HCl}, \mathrm{NaOH}, \mathrm{NH}_{3} \mathrm{OH}$, $\mathrm{MeOH}$, dapar fosfat $0,1 \mathrm{M} \mathrm{pH} \mathrm{7,} \mathrm{air} \mathrm{suling,}$ hewan coba mencit (Mus musculus) Galur deuch democratic Yokohama (ddY), tikus (Wistar), dan kelinci (New Zealand).

Peralatan yang digunakan adalah sistem generator radioisotop ${ }^{90} \mathrm{Sr} /{ }^{90} \mathrm{Y}$ yang menghasilkan ${ }^{90} \mathrm{Y}$, pencacah alpha beta simple counter Ludlum Model 3030, spektrometer gamma (Tennelec) dengan detektor HP-Ge, dan liquid scintillation and luminescence counters (LSC) MicroBeta Perkin Elmer.

Larutan radionuklida ${ }^{90} \mathrm{Y}$ dan hasil penandaan ${ }^{90}$ Y-EDTMP yang digunakan pada penelitian ini sama dengan radionuklida ${ }^{90} \mathrm{Y}$ dan ${ }^{90} \mathrm{Y}$-EDTMP yang telah dilaporkan dalam uji biodistribusi. ${ }^{4}$

\section{Prosedur kerja}

\section{Uji clearance ${ }^{90}$ Y-EDTMP pada hewan coba tikus}

Hewan coba tikus normal diinjeksi dengan sediaan radiofarmaka ${ }^{90}$ Y-EDTMP secara intravena dengan aktivitas $\pm 40 \mu \mathrm{Ci}$ dan volume $200 \mu \mathrm{L}$. Tikus setelah diinjeksi dengan ${ }^{90} \mathrm{Y}$-EDTMP ditempatkan pada metabolic cage kemudian urine dan feses tikus ditampung secara terpisah pada wadah yang telah tersedia dengan waktu pengambilan setiap 24 jam. Selama masa karantina hewan coba diberi makan dan minum yang selalu tersedia (ad libitum). Suhu dan kelembaban ruangan dijaga antara $18-26^{\circ} \mathrm{C}$ dan $40-70 \% \mathrm{RH}$. Urine dan feses yang ditampung secara terpisah diambil dalam rentang waktu 24 jam, 48 jam, 72 jam, dan 192 jam. Pencacahan atau pengukuran radioaktivitasnya dilakukan menggunakan gamma counter. ${ }^{13}$ Jumlah tikus yang digunakan untuk pengamatan ini adalah sebanyak 3 ekor.

\section{Uji pirogenitas ${ }^{90}$ Y-EDTMP pada hewan coba kelinci}

Penentuan suhu tubuh kelinci dilakukan dengan memasukkan ujung thermocople (OD $0.4 \mathrm{~mm}$ ) ke dalam rectum masing-masing kelinci sedalam $\pm 7,5 \mathrm{~cm}$. Suhu tubuh dicatat setelah lima menit, selanjutnya suhu tubuh dicatat setiap 30 menit sebanyak dua kali. Kelinci yang digunakan dalam pengujian harus dalam keadaan sehat yaitu kelinci yang suhu tubuhnya di bawah $39,8{ }^{\circ} \mathrm{C}$ sehingga data yang dihasilkan betul-betul menunjukkan keadaan yang sebenarnya. ${ }^{10}$ Vena kuping kelinci yang akan disuntik 
diusap dengan alkohol 70\%, kemudian $1 \mathrm{ml}$ larutan sampel ${ }^{90}$ Y-EDTMP disuntikkan melalui vena tersebut. Suhu masing-masing kelinci dicatat setelah rentang waktu 1, 2, dan 3 jam setelah penyuntikkan. Dari perbedaan antara suhu kontrol rata-rata dengan suhu rata-rata setelah penyuntikkan dapat diketahui kenaikan suhu hewan percobaan tersebut. Hasil ini menunjukkan bahwa sediaan tersebut bebas pirogen atau tidak. ${ }^{13,14}$

\section{Uji keamanan ${ }^{90}$ Y-EDTMP pada hewan coba mencit}

Hewan coba mencit normal diinjeksi dengan sediaan radiofarmaka ${ }^{90} \mathrm{Y}$-EDTMP secara intravena dengan aktivitas $\pm 40 \mu \mathrm{Ci}$ dan volume maksimum $200 \mu \mathrm{L}$ yang mengandung 6,9 x 10-8 mol/injeksi. Mencit kemudian ditempatkan pada kandang policarbonat yang dialasi dengan sekam padi dan dilakukan pengamatan selama 14 hari. ${ }^{10,11}$ Selama masa pengamatan ini hewan coba diberi makan dan minum yang selalu tersedia (ad libitum) dan disimpan dalam ruang isolasi serta suhu dan kelembaban ruangan dijaga antara $18-26^{\circ} \mathrm{C}$ dan $40-70 \%$ RH.

\section{HASIL DAN PEMBAHASAN}

Itrium-90 hasil elusi sebelum digunakan untuk penandaan EDTMP diuji kualitasnya dengan parameter kemurnian radiokimia, pengotor ${ }^{90} \mathrm{Sr}$, dan pengotor gamma. Hasilnya dapat dilihat pada Tabel 1 .

Tabel 1. Hasil uji kualitas ${ }^{90} \mathrm{Y}$ hasil elusi

\begin{tabular}{ll}
\hline \multicolumn{1}{c}{ Parameter } & \multicolumn{1}{c}{ Hasil } \\
\hline $\begin{array}{l}\text { Kemurnian } \\
\text { radiokimia }\left({ }^{90} \mathrm{YCl}_{3}\right)\end{array}$ & $96,65 \pm 2,87 \%$ \\
\hline Pengotor ${ }^{90} \mathrm{Sr}$ & $\begin{array}{l}0,0091 \pm 0,0085 \\
\mathrm{~Bq}^{90} \mathrm{Sr} / \mathrm{Bq}{ }^{90} \mathrm{Y}\end{array}$ \\
\hline Pengotor Gamma & Tidak terdeteksi \\
\hline
\end{tabular}

Hasil uji kualitas ${ }^{90} \mathrm{Y}$ hasil elusi menunjukkan bahwa kemurnian radiokimia ${ }^{90} \mathrm{Y}$ telah memenuhi syarat dengan hasil diatas $95 \%$.

Hasil penandaan EDTMP dengan ${ }^{90} \mathrm{Y}$ diuji kemurniannya menggunakan metode kromatografi kertas. Fasa diam menggunakan kertas whatman 3MM dan fasa gerak campuran dari ammonium hidroksida, metanol, dan air dengan perbandingan 0,2:2:4. ${ }^{4}$ Dari uji penandaan ${ }^{90}$ Y-EDTMP tersebut diperoleh kemurnian radiokimia 92,70\%. Kromatogram uji kemurnian radiokimia ${ }^{90}$ Y-EDTMP ditampilkan pada Gambar 1.

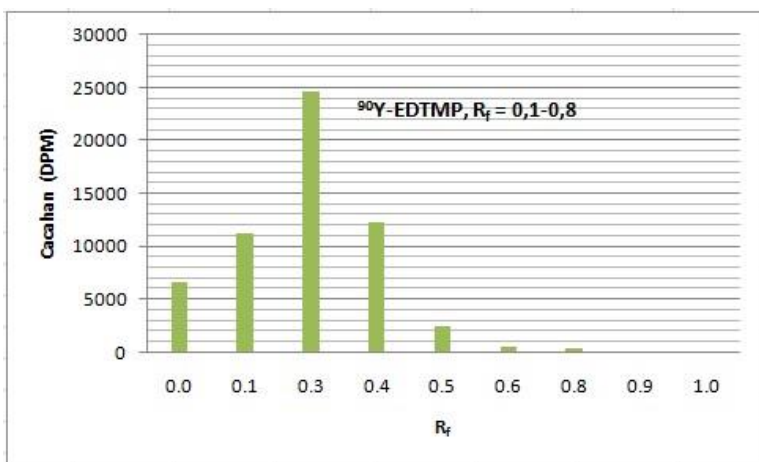

Gambar 1. Kromatogram uji kemurnian radiokimia ${ }^{90}$ Y-EDTMP

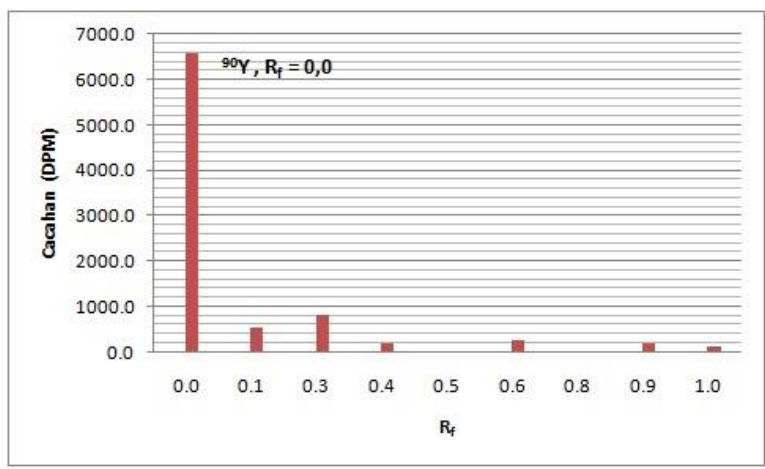

Gambar 2. Kromatogram ${ }^{90}$ Y sebelum penandaan EDTMP

Penelitian sebelumnya menunjukkan bahwa ${ }^{90}$ Y-EDTMP berada di $\mathrm{R}_{\mathrm{f}}=0,5-0,9$ dan ${ }^{90} \mathrm{Y}$ di $\mathrm{R}_{\mathrm{f}}=0,0 .{ }^{5}$ Uji kemurnian ${ }^{90}$ Y-EDTMP yang telah dilakukan berada di $\mathrm{R}_{\mathrm{f}}=0,1-0,8$ (Gambar 1) dan ${ }^{90} \mathrm{Y}$ di $\mathrm{R}_{\mathrm{f}}=0,0$ (Gambar 2). hal ini mungkin disebabkan oleh kondisi bahan yang digunakan saat pengujian.

\section{Uji clearance ${ }^{90}$ Y-EDTMP pada hewan coba tikus}

Uji clearance ${ }^{90}$ Y-EDTMP terhadap hewan coba mencit ditampilkan pada Gambar 3. Hasil pengujian menunjukkan bahwa ${ }^{90} \mathrm{Y}$ diekskresikan melalui urine lebih 
banyak dari pada feses. Durasi 0-24 jam lebih banyak dieksresikan dari pada durasi berikutnya terlihat trendnya menurun baik di urine maupun di feses. Hasil ekskresi juga dipengaruhi oleh jumlah urine maupun feses yang dihasilkan hewan coba juga lama waktu penampungan dari urine dan feses tersebut. Hal ini terlihat pada Gambar 3 atau Tabel 2 No.3 dan 4, dimana terdapat perbedaan jumlah urine, feses, dan waktu tampung. tabel 2 menunjukkan bahwa ${ }^{90} \mathrm{Y}$ diekskresikan terbanyak dalam waktu 48 jam. Itrium-EDTMP yang terekskresikan selama 192 jam melalui urine sebanyak $49,7 \%$ dan melalui feses $14,59 \%$. Total ekskresi ${ }^{90} \mathrm{Y}$ selama 192 jam adalah $64,57 \%$ (Tabel 2).

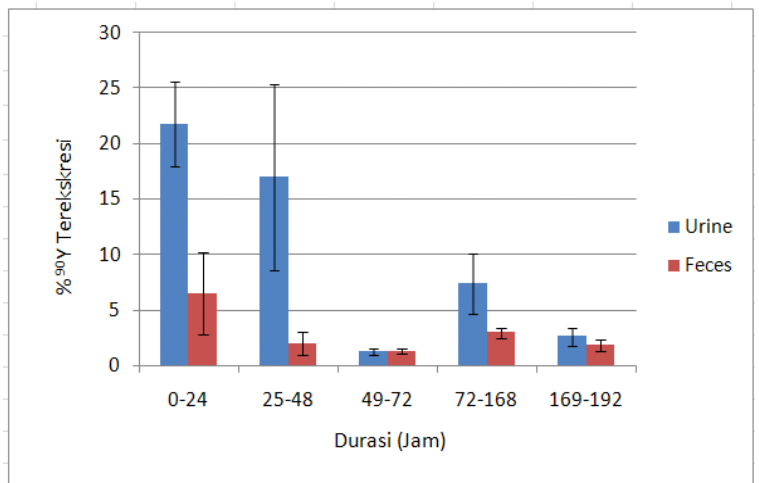

Gambar 3. Profil ekskresi ${ }^{90}$ Y-EDTMP pada hewan coba tikus

\section{Tabel 2. Uji clearance ${ }^{90}$ Y-EDTMP terhadap hewan coba tikus}

\begin{tabular}{clcc}
\hline No. & $\begin{array}{c}\text { Durasi } \\
(\text { Jam) }\end{array}$ & $\begin{array}{c}\text { Aktivitas di } \\
\text { Urine (\%) }\end{array}$ & $\begin{array}{c}\text { Aktivitas } \\
\text { di Feses } \\
(\%)\end{array}$ \\
\hline 1 & $0-24$ & $21,75 \pm 3,81$ & $6,47 \pm 3,71$ \\
\hline 2 & $25-48$ & $16,97 \pm 8,37$ & $2,02 \pm 1,02$ \\
\hline 3 & $49-72$ & $1,26 \pm 0,29$ & $1,30 \pm 0,21$ \\
\hline 4 & $73-168$ & $7,38 \pm 2,67$ & $2,97 \pm 0,47$ \\
\hline 5 & $169-192$ & $2,62 \pm 0,80$ & $1,83 \pm 0,55$ \\
\hline Sub Total & $\mathbf{4 9 , 9 7}$ & $\mathbf{1 4 , 5 9}$ \\
\hline \multicolumn{4}{c}{$\mathbf{6 4 , 5 7} \%$} \\
\hline
\end{tabular}

Berdasarkan persamaan pada Gambar 4 diperoleh waktu paruh biologis ${ }^{90} \mathrm{Y}$-EDTMP dalam tubuh hewan coba adalah 84,2 jam.

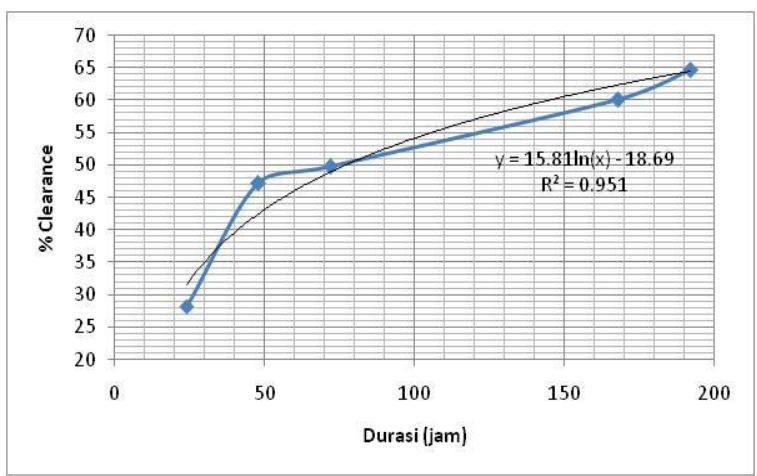

\section{Gambar 4. Profil gabungan (urine dan feses) ekskresi ${ }^{90}$ Y-EDTMP pada hewan coba tikus}

Waktu paruh yaitu waktu yang diperlukan oleh zat dalam sistem biologi berkurang hingga tinggal setengah dari jumlah awalnya karena proses biologi. Waktu paruh efektif merupakan waktu yang diperlukan radionuklida yang terkandung dalam makhluk hidup berkurang menjadi separuh dari jumlah semula sebagai hasil kombinasi antara peluruhan radioaktif dan eliminasi biologis. Waktu paruh efektif ${ }^{90}$ Y-EDTMP pada hewan coba adalah 36,5 jam. Jadi waktu tinggal (residence time) yang merupakan waktu paruh efektif dibagi $\ln (2)$ adalah 52,7 jam. ${ }^{8}$

\section{Uji pirogenitas ${ }^{90}$ Y-EDTMP pada hewan coba kelinci}

Hasil uji pirogen (Tabel 3) menunjukkan kenaikan suhu total dari 3 ekor kelinci sebesar $1,17^{\circ} \mathrm{C}$. Berdasarkan International Pharmacopoeia, larutan ${ }^{90}$ Y-EDTMP yang digunakan telah memenuhi syarat bebas pirogen, karena kenaikan jumlah suhu ke 3 ekor kelinci tersebut $<1.4{ }^{\circ} \mathrm{C}$ dan kenaikan suhu individual kelinci $<0.6{ }^{\circ} \mathrm{C} .{ }^{12}$

Tabel 3. Data uji pirogenitas larutan ${ }^{90}$ Y-EDTMP

\begin{tabular}{|c|c|c|c|c|c|c|}
\hline \multirow[t]{2}{*}{ No.Kelimci } & \multirow{2}{*}{$\begin{array}{c}\text { Kontrol } \\
\left({ }^{0} \mathrm{C}\right)\end{array}$} & \multicolumn{3}{|c|}{ Suhu (C) } & \multirow{2}{*}{$\begin{array}{c}\text { Rata-lata } \\
\text { (C) }\end{array}$} & \multirow{2}{*}{$\begin{array}{l}\text { Kenaikan } \\
\text { Suhu }\left({ }^{0} \mathrm{C}\right)\end{array}$} \\
\hline & & Kesatu & Kedua & Ketiga & & \\
\hline A & 37,35 & 38,00 & 38,00 & 38,00 & 38,00 & 0,47 \\
\hline B & 38,10 & 38,50 & 38,60 & 38,60 & 38,57 & 0,47 \\
\hline $\mathrm{C}$ & 37,80 & 38,00 & 38,00 & 38,10 & 38,03 & 0,23 \\
\hline \multicolumn{6}{|c|}{ Kenaikan suhu tatal } & 1,17 \\
\hline $\begin{array}{l}\text { Catatan: } \\
\text { 1. Setiap } \\
\text { 2. Kenaike }\end{array}$ & otal har & ${ }^{\circ} \mathrm{C}$ & & & & \\
\hline
\end{tabular}




\section{Uji keamanan ${ }^{90}$ Y-EDTMP pada hewan coba mencit}

Uji keamanan ${ }^{90} \mathrm{Y}$-EDTMP pada mencit dilakukan melalui pengamatan selama 14 hari terhadap 5 ekor mencit. Hasil pengamatan menunjukkan tidak satupun dari hewan coba mencit mengalami kelainan seperti: gelisah, tidak lincah, tidak bergairah, bulu kusam dan rontok, maupun mati. Uji keamanan menurut Parasuraman adalah untuk pengujian toksisitas akut. jika selama pengamatan ada hewan yang mati, memungkinkan dosis yang digunakan telah termasuk dosis yang mematikan 50\% (LD50). ${ }^{11}$ Dengan demikian diketahui dosis ${ }^{90}$ Y-EDTMP yang digunakan masih dalam batasan aman dan belum termasuk pada dosis yang mematikan. Pengujian ini merupakan pengujian pendahuluan untuk memprediksi keamanan dari penggunaan ${ }^{90} \mathrm{Y}$-EDTMP. Selanjutnya perlu dilakukan pengujian toksisitas untuk mengetahui nilai $\left(\mathrm{LD}_{50}\right)$ dan dosis maksimal yang masih dapat ditoleransi hewan coba.

\section{KESIMPULAN}

Senyawa ${ }^{90}$ Y-EDTMP yang diekskresikan melalui urine dan feses masih dapat dideteksi hingga 192 jam dengan jumlah $64,57 \%$ dari dosis yang diberikan pada hewan coba. ${ }^{90}$ Y-EDTMP memiliki waktu paruh biologis dalam tubuh hewan coba 84,2 jam, waktu paruh efektif 36,5 jam dan waktu tinggal (residence time) 52,7 jam. Persyaratan radiofarmaka lainnya telah dipenuhi, yaitu sediaan ini telah dibuktikan bebas pirogen dan dosis ${ }^{90}$ Y-EDTMP yang digunakan masih dalam batas aman.

\section{UCAPAN TERIMA KASIH}

Ucapan terima kasih disampaikan kepada Pusat Teknologi Radioisotop dan Radiofarmaka (PTRR) BATAN yang telah memfasilitasi penelitian ini dan kepada Dra. Siti Darwati, M.Sc, Dr. Rohadi Awaludin, serta V. Yulianti S. M.Farm yang telah membantu serta memberikan saran.

\section{DAFTAR RUJUKAN}

1. Sohaib M, Ahmad M, Jehangir M, Perveen A. Ethylene diamine tetramethylene phosphonic acid labeled with various beta(-)-emitting radiometals: labeling optimization and animal biodistribution. Cancer Biotherapy and. Radiopharmaceutical. 2011;26(2):159-64.

2. Chakravarty R, Pandey U, Manolkar RB, Dash A, Venkatesh M, Pillai MRA. Development of an electrochemical ${ }^{90} \mathrm{Sr}^{90}{ }^{90} \mathrm{Y}$ generator for separation of ${ }^{90} \mathrm{Y}$ suitable for targeted therapy. Nuclear Medicine and Biology. 2008;35(2):245-53.

3. Petrovic D, Nikolic N, Stankovic D, Djokic D. Electrochemical separation of 90-Yttrium in the electrochemical ${ }^{90} \mathrm{Sr} /{ }^{90} \mathrm{Y}$ generator and its use for radiolabelling of DOTA-conjugated somatostatin analog [DOTA0, Tyr3] octreotate. Nuclear Technology \& Radiation Protection. 2012;27(3):260-8.

4. Sulaiman, Aguswarini S, Karyadi, Chairuman, Setiawan G, Subur M, et al. Uji biodistribusi senyawa ${ }^{90} \mathrm{Y}$-sitrat dan ${ }^{90} \mathrm{Y}$-EDTMP yang ditandai dengan ${ }^{90} \mathrm{Y}$ hasil elusi dari generator ${ }^{90} \mathrm{Sr} /{ }^{90} \mathrm{Y}$. Prosiding Pertemuan Ilmiah Tahunan Perhimpunan Kedokteran Nuklir Indonesia (PKNI), Perhimpunan Kedokteran dan Biologi Nuklir Indonesia (PKBNI), dan Pusat Teknologi Radioisotop dan Radiofarmaka (PTRR); 2015. p. 1-8.

5. Pandey U, Kameswaran M, Subramanian S, Chakrafarty R, Sarma HD, Samuel G, et al. Development of Radiopharmaceuticals Based on ${ }^{188} \mathrm{Re}$ and ${ }^{90} \mathrm{Y}$ for Radionuclide Therapy at Barc. In IAEA radioisotopes and radiopharmaceuticals series, no. 5. Yttrium-90 and Rhenium-188 radiopharmaceuticals for radionuclide therapy; 2015; Vienna, Austria. IAEA; 2015. p. 82-106.

6. Sulaiman, Aguswarini S, Karyadi, Chairuman, Setiawan G, Subur M, et al. Optimasi penggunaan $\mathrm{HCl}$ sebagai larutan pengelusi. Urania. 2015;21(2):87-94.

7. Ramli M, Hidayat B, Aguswarini S, Karyadi, Ardiyatno CN, Subur M., et al. Preclinical study of ${ }^{177} \mathrm{Lu}$-DOTA-trastuzumab: a potential radiopharmaceutical for therapy of breast cancer postive HER-2. Jurnal Ilmu Kefarmasian Indonesia. 2013;11(2): 116-22.

8. Khalid M, Bokhari TH, Ahmad M, Bhatti HN, Iqbal M, Ghaffar A, et al. Evaluation of carrier added and no carrier added ${ }^{90}$ Y-EDTMP as bone seeking therapeutic radiopharmaceutical. Pakistan Journal of Pharmaceutical Sciences. 
2014;27(4):813-8.

9. Riccabona G. Dosimetry in Radionuclide Therapy. In: Therapeutic applications of radiopharmaceuticals, IAEA-TECDOC1228; 1999 Jan 18-22; Hyderabad, India. Vienna, Austria: IAEA; 2001

10. Hardi A, Rista S, Mutalib A, Sugiharto Y, Dini R, Aguswarini S. Preparasi, biodistribusi dan clearance senyawa pengkontras MRI Gd-DTPA-PAMAM G4-NIMOTUZUMAB melalui simulasi menggunakan ${ }^{153}$ Gd-DTPA-PAMAM G4-NIMOTUZUMAB. Seminar Nasional VI SDM Teknologi Nuklir; 2010 November 18; Yogyakarta, Indonesia.

11. Parasuraman S. Toxicological screening. Journal of Pharmacology \& Pharmacotherapeutics. 2011;2(2):74-9.
12. International Pharmacopoeia. 5th ed. Geneva: World Health Organization; 2015.

13. Ranjbar H, Samani AB, Beiki D, Arani SS, Maragheh MG. Evaluation of $153 \mathrm{Sm} / 177$ Lu-EDTMP mixture in wild-type rodents as a novel combined palliative treatment of bone pain agent. Journal of Radioanalytical and Nuclear Chemistry. 2015;303:71-9.

14. Samani AB, Maragheh MG, Jalilian AR, Meftahi M, Arani SS, Moradkhani S. Production, quality control and biological evaluation of Sm-EDTMP in wild-type rodents. Iranian Journal of Nuclear Medicine. 2009;17(2):12-9. 